\title{
Effect of Chromate-Copper-Boron preservative treatment on physical and mechanical properties of Raj koroi (Albizia richardiana) wood
}

\author{
S. A. Shanu ${ }^{1}$, A. K. Das ${ }^{1,2 *}$, M. M. Rahman ${ }^{1}$, M. Ashaduzzaman ${ }^{1}$ \\ ${ }^{1}$ Forestry and Wood Technology Discipline, Khulna University, Khulna-9208, Bangladesh. \\ ${ }^{2}$ Pulp and Paper Technology, Asian Institute of Technology, Klong Luang, Pathumthani-12120, Thailand.
}

\begin{abstract}
This experiment was carried out to analyze the effects of CCB (chromate-copper-boron) preservative treatment on physical and mechanical properties of Albizia richardiana wood using dipping method. Retention of preservative was maximum at $8 \%$ concentration of the preservatives. Based on the retention at this concentration, the physical and mechanical properties of the treated wood were examined. The density of untreated A. richardiana wood was $521 \mathrm{~kg} / \mathrm{m}^{3}$. It changed to $542 \mathrm{~kg} / \mathrm{m}^{3}$ on treatment. This increase in density by $2.30 \%$ for treated wood was significant. On the other hand, modulus of rupture (MOR) increased significantly from 93 to $107 \mathrm{~N} / \mathrm{mm}^{2}$ on treatment of the wood. The modulus of elasticity (MOE) increased from 3205 to $4861 \mathrm{~N} / \mathrm{mm}^{2}$. Physical and mechanical properties of the wood improved by treating with CCB preservative.
\end{abstract}

Keywords: Chromate-copper-boron; Albizia richardiana; Physical properties; Mechanical properties

\section{Introduction}

Wood is the world's most valuable and abundant renewable natural resources (Lahiry, 2001). It is the material used by man for thousands of years without precise knowledge of its properties (Wangaard, 1981). Wood is always been a pre-eminent construction and industrial material. Its low cost and availability in various forms and sizes, together with such properties such as relatively great strength with respect to weight, ease of shaping, low heat conductivity qualities etc., made it outstanding material (FAO, 1986).

The primary importance of the preservation treatment of wood is to increase the life of the material in service. As such the ultimate cost of the product decreases in the long run by avoiding the need for frequent replacements (Jayanetti, 1986). It is well conceived that the extension of the service life of timber by the application of appropriate preservatives has significant effect in the field of wood utilization (Jayanetti, 1986). Preservative treated products give a desired result in service performance (Lahiry, 2001).

Preservative treatment is done with a variety of preservatives chemicals. Due to arsenic toxicity of CCA (chrome-copper-arsenic), it is not used now. Today, increasing emphasis is placed on using preservatives that are targeted more specifically to particular applications. Such preservatives are safer to use and potentially less damaging to the environment. To this end, a water borne preservative named CCB is used for this study in which the components are sodium dichromate, copper sulfate and boric acid. In $\mathrm{CCB}$ preservatives, copper acts as a fungicide, boron as a biocide and chromium as fixative (Lahiry, 2001). Boron compounds, usually in the form of boron salts, have long been known and used as effective wood preservatives for timber (Cartlidge et al., 1995).

The preservative treatment of wood modifies its properties making it dimensionally stable and durable for efficient utilization (Winandy, 1991).

Albizia richardiana (raj koroi) locally known as chambal is a promising fast growing species with shallow root system and light demanding species. This is an exotic from Madagascar (Africa) and planted as road side avenue tree in Bangladesh for its beautiful habitat since British period. It also occurs in the forest of Chittagong Hill Tracts (Kaptai) and Chittagong and in the village of Northern districts. It is one of the most important species of coastal area in Bangladesh (Latif et al., 1987). In Bangladesh this tree is used for furniture and frame manufacturing, house post, roofing, etc. (Das and Alam, 2001). It is a useful species for social forestry (BFD, 2011).

\footnotetext{
*Corresponding author: E-mail: atanu03ku@yahoo.com
} 
In this study, it was tried to determine the effect of CCB preservative treatment on physical and mechanical properties of $A$. richardiana wood.

\section{Materials and methods}

Two Albizia richardiana trees, 14-years-old, grown in Khulna University Campus, Khulna (22 48' $0^{\prime \prime} \mathrm{N}$ and $89^{\circ} 33^{\prime}$ $0^{\prime \prime}$ E), Bangladesh were collected for this study. Samples were collected from the bottom, middle and top containing heartwood. The samples were in the form of $35.0 \mathrm{~cm} \times 5.5 \mathrm{~cm}$ $\times 2.5 \mathrm{~cm}$ for MOR and MOE tests. The size of sample for physical properties was $5.0 \mathrm{~cm} \times 5.0 \mathrm{~cm} \times 2.5 \mathrm{~cm}$. The specimen for compression strength perpendicular to grain test was in the form of $8.0 \mathrm{~cm} \times 4.0 \mathrm{~cm} \times 2.0 \mathrm{~cm}$ and compression strength parallel to grain tests was in the form of $8.0 \mathrm{~cm} \times 3.0$ $\mathrm{cm} \times 3.0 \mathrm{~cm}$. The converted samples were dried in open air for 30 days to reduce the moisture content of the wood samples. The samples were dried in the oven at $105^{\circ} \mathrm{C}$ to get constant weight before treating with preservative.

Chromate-copper-boron (CCB) preservative was used in this study. The desired CCB preservative was made by mixing of sodium dichromate, copper sulfate and boric powder as salt-based ratio of 2:2:1 respectively (Lahiry, 1996).

All the wood samples were dipped into the preservative solutions of 4, 6, 8 and $10 \%$ concentrations for 72 hours. After the desired duration, the treated samples were taken out from preservative solutions step by step, removed excess preservative from the surface of the samples and placed on polythene sheet for air drying.

The volumetric analysis was used to calculate preservative retention of wood samples. Oven dry weight before treatment and oven dry weight after treatment were taken to determine the retention. The difference of the two weights was the weight of preservative solution penetrated into the sample. Retention was expressed as $\mathrm{kg} / \mathrm{m}^{3}$.

\section{Results and discussions}

\section{Retention of CCB preservative}

Albizia richardiana wood was treated with four different preservative concentrations viz., 4, 6, 8 and $10 \%$ for 72 hours. The maximum retention was $32.2 \mathrm{~kg} / \mathrm{m}^{3}$ with $8 \%$ concentration while the lowest retention was $20.6 \mathrm{~kg} / \mathrm{m}^{3}$ with $4 \%$ concentration (Fig. 1). The retention for 6 and $10 \%$ concentration level were 25.4 and $23.4 \mathrm{~kg} / \mathrm{m}^{3}$ respectively (Fig. 1). Analysis of variance reveled that there had been significant variation for retention of preservatives among the four different concentrations $(\mathrm{F}=12.92, \mathrm{df}=3$ and $\mathrm{P}<0.05)$.
The concentration of $8 \%$ was considered enough for the treatment. Thus, wood samples treated with $8 \%$ concentration were evaluated for the physical and mechanical properties.

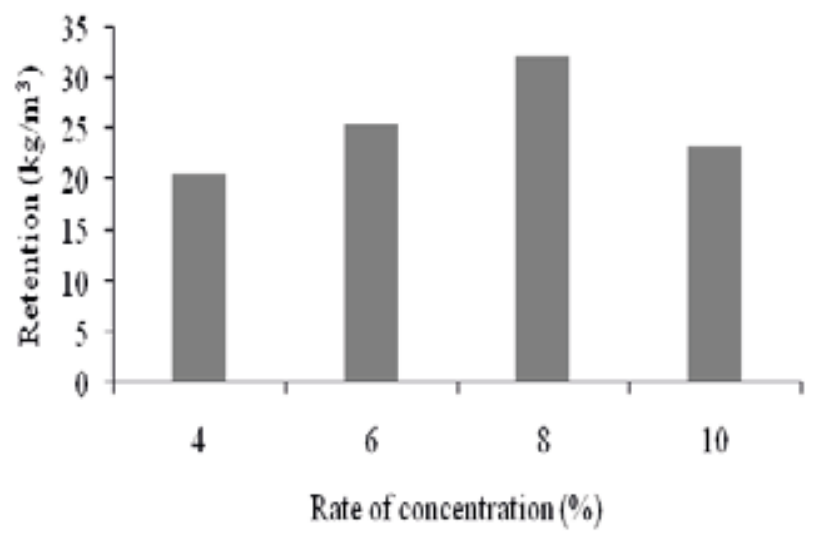

Fig. 1. Average retention of CCB preservatives

\section{Effects on physical properties}

The density of untreated was $521 \mathrm{~kg} / \mathrm{m}^{3}$ and that of the treated wood of Albizia richardiana was $542 \mathrm{~kg} / \mathrm{m}^{3}$ (Fig. 2). From the statistical analysis, it was observed that there was significant difference $(\mathrm{t}=3.76$, $\mathrm{df}=16, \mathrm{P}<0.05)$. The density of $A$. richardiana wood increased by only $2.3 \%$ on preservative treatment. Any treatment that alters the structure of the wood or composition and hygroscopic character may influence its physical properties (Wangaar, 1979). Ashaduzzaman et al. (2007) reported that density of Sonneratia apetala increased $18 \%$ due to waterborne preservatives. The density of $A$. richardiana was lower than Acacia nilotica $\left(882 \mathrm{~kg} / \mathrm{m}^{3}\right)$ for both treated and untreated (Alam et al., 2015). Cocos nucifera showed lower density (370 to $430 \mathrm{~kg} / \mathrm{m}^{3}$ ) than $A$. richardiana (Rana et al., 2015).

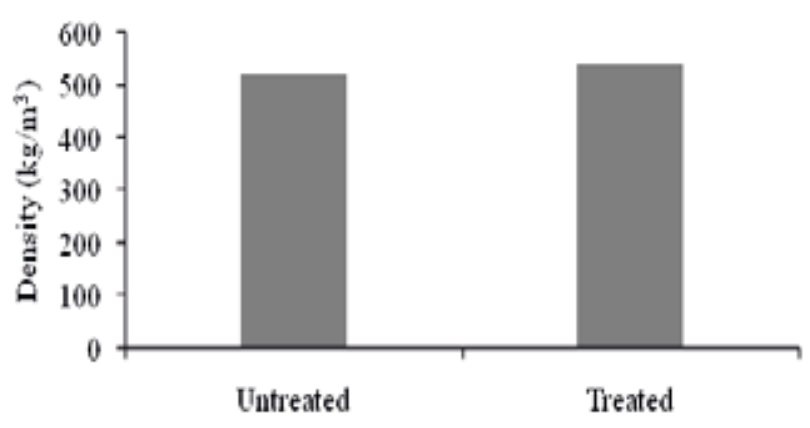

Types of wood

Fig. 2. Effect of CCB preservative treatment on density of A. richardiana wood 
It was found that the moisture content of untreated and treated wood of $A$. richardiana were 27.6 and $26.0 \%$ (Fig. 3). Untreated wood was not significantly different $(\mathrm{t}=1.55$, df $=16, \mathrm{P}>0.05)$ from treated wood for moisture content. The moisture content of $A$. richardiana wood decreased to $4.80 \%$ due to preservative treatment. On the other hand Lahiry (1998) found that moisture content increased $4 \%$ for boron treated Mangifera indica.

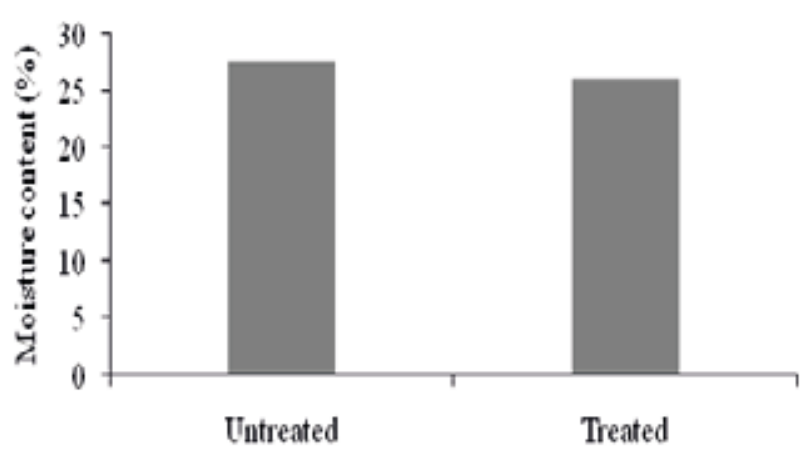

Types of wood

Fig. 3. Effect of CCB preservative treatment on moisture content of $A$. richardiana wood

Fig. 4. shows that the radial shrinkage was 2.78 , tangential 4.30 and volumetric $7.22 \%$ of untreated wood of $A$. richardiana. Radial, tangential and volumetric shrinkage of treated wood of $A$. richardiana was $2.48,3.67$ and $6.27 \%$ respectively (Fig. 4). Treated wood was significantly $(t=3.49$, df $=16, \mathrm{P}<0.05$ for radial, $\mathrm{t}=5.89, \mathrm{df}=16, \mathrm{P}<0.05$ for tangential and $\mathrm{t}=1.97$, $\mathrm{df}=16, \mathrm{P}<0.05$ for volumetric) different from untreated wood. The radial, tangential and volumetric shrinkage of $A$. richardiana wood decreased by $10.8,14.7$ and $13.2 \%$ for preservative treatment.

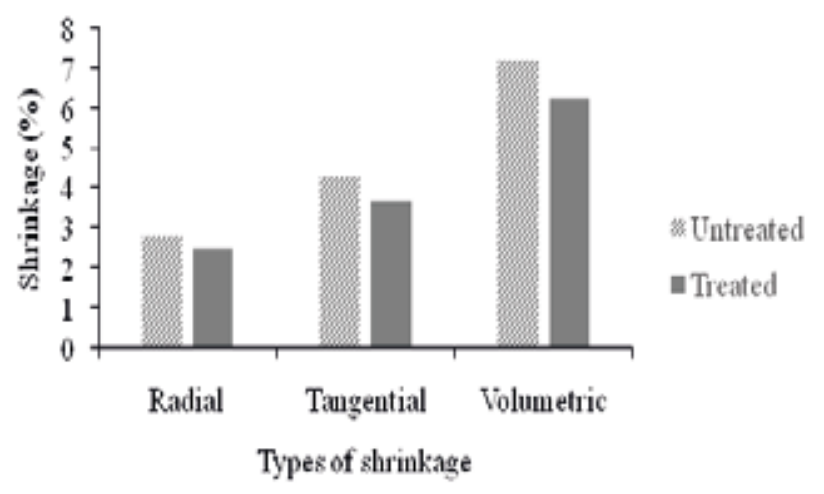

Fig. 4. Effect of CCB preservative treatment on shrinkage of $A$. richardiana wood

\section{Effect on mechanical properties}

Untreated wood of $A$. richardiana showed modulus of rupture (MOR) $97.9 \mathrm{~N} / \mathrm{mm}^{2}$ and treated wood showed 106.3 $\mathrm{N} / \mathrm{mm}^{2}$ (Fig. 5). Statistical analysis showed that there was significant $(\mathrm{t}=3.84, \mathrm{df}=16, \mathrm{P}<0.05)$ difference between two types of wood. By preservative treatment, the MOR of $A$. richardiana wood increased by $5.52 \%$. It was reported by Kabir et al. (1994) that MOR increased by $11.11 \%$ for the treated wood of Eucalyptus camaldulensis. Ashaduzzaman et al. (2007) stated that MOR of Soneratia apetala increased by $8.50 \%$ due to waterborne preservatives. Alam et al. (2015) found MOR $127 \mathrm{~N} / \mathrm{mm}^{2}$ for A. nilotica and it was higher than that of $A$. richardiana. According to Rana et al. (2015) MOR of $C$. nucifera was 27.1 to $37.7 \mathrm{~N} / \mathrm{mm}^{2}$ which was lower than MOR of $A$. richardiana.

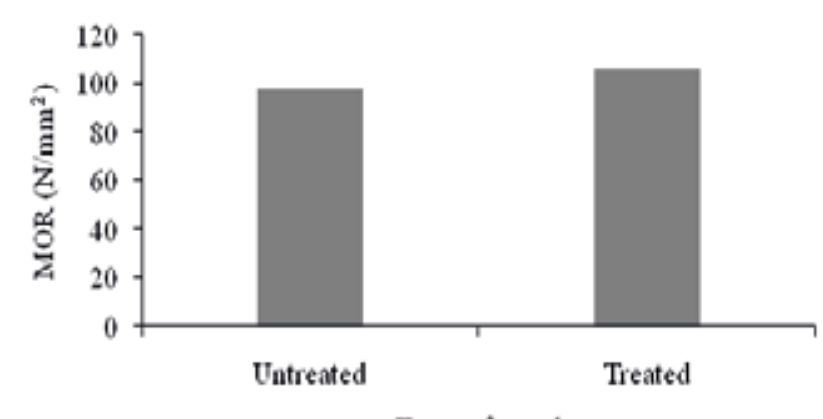

Fig. 5. Effect of CCB preservative treatment on MOR of $A$. richardiana wood

Fig. 6. shows that the modulus of elasticity (MOE) for untreated and treated wood of $A$. richardiana were 3783 and $3947 \mathrm{~N} / \mathrm{mm}^{2}$. Significant difference $(\mathrm{t}=4.86, \mathrm{df}=16, \mathrm{P}<0.05)$ was found between two types of wood for MOE. The MOE of $A$. richardiana wood increased by $4.3 \%$ on preservative treatment. Kabir et al. (1994) found that MOE increased by $3 \%$ due to preservative treatment of Acacia mangium wood. MOE of $S$. apetala increased by $4.30 \%$ by treating with waterborne preservatives (Ashaduzzaman et al., 2007). The MOE of $A$. richardiana was higher in comparison to MOE of A. nilotica $\left(1950 \mathrm{~N} / \mathrm{mm}^{2}\right)$ (Alam et al., 2015). C. nucifera showed MOE 2310 to $2620 \mathrm{~N} / \mathrm{mm}^{2}$ (Rana et al., 2015). This finding was lower than MOE of $A$. richardiana.

Compression strength perpendicular to grain for untreated and treated wood of $A$. richardiana were 14.57 and 16.54 $\mathrm{N} / \mathrm{mm}^{2}$ (Fig. 7). Untreated wood was significantly $(\mathrm{t}=3.78$, $\mathrm{df}=16, \mathrm{P}<0.05)$ different from treated wood. Preservative treatment increased the compression strength of $A$. richardiana wood $9.11 \%$. 


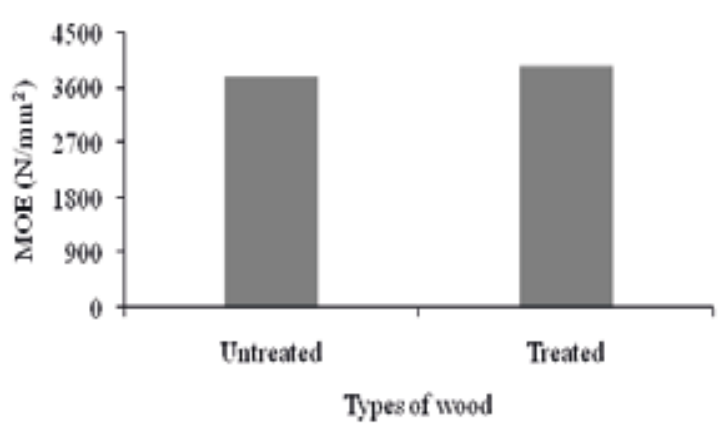

Fig. 6. Effect of CCB preservative treatment on MOE of $A$. richardiana wood

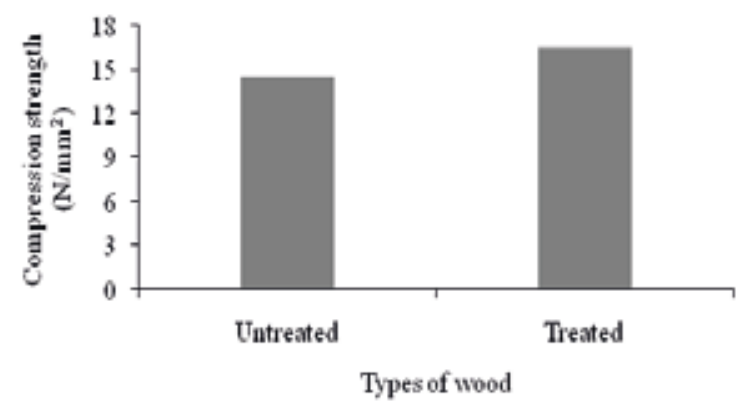

Fig. 7. Effect of CCB preservative treatment on compression strength of $A$. richardiana wood

\section{Conclusion}

Albizia richardiana showed the highest retention with $8 \%$ concentration of CCB for 72 hours. Due to $8 \% \mathrm{CCB}$ preservative treatment, most of the physical and mechanical properties of $A$. richardiana increased from 3 to $14 \%$. The preservatives treatment did not cause any serious problem in case of the strength properties of wood. Thus the CCB treated A. richardiana can be used satisfactorily as interior exercise like furniture and frame manufacturing, house post, roofing etc.

\section{Reference}

Ashaduzzaman M, Islam MS, Hannan MO and Islam MN (2007), Effects of Preservative treatment by CCA-C Preservative on Strength Properties of Sonneratia apetala Wood. J Indian Acad Wood Sci, 4(1\&2): 47-52.

Alam J, Das AK, Rahman MM and Islam MA (2015), Effect of waterlogged condition on wood properties of Acacia nilotica (L) Debile tree. Bangladesh J. Sci. Ind. Res. 50(2): 71-76,
B F D ( $\left.\begin{array}{llll}2 & 0 & 1 & 1\end{array}\right)$. F o r e $\mathrm{s} t \mathrm{t} y \mathrm{p}$ e $\mathrm{s}$. http://www.bforest.gov.bd/index.php/forestcategory/vi llage-forests.

Cartlidge DM, Ashby GR and Wylie L (1995), Groundline treatment of poles using boron rods. In proceedings of the Canadian Wood Preservers' Associations, 16: 133-149.

Das DK and Alam MK (2001), Trees of Bangladesh. Bangladesh Forest Research Institute, Chittagong, Bangladesh. 2: 342.

FAO (1986), Wood preservation manual. FAO Forestry Paper 76, FAO, Rome, pp-1-135.

Jayanetti DL (1986), Wood preservation manual. FAO-Forestry Paper, No.76, pp-ii - 152.

Kabir MF, Bhattacharjee DK, Sattar MA and Elias GNM (1994), Effect of preservative treatment on strength properties of Mangium (Acacia mangium). Bangladesh Journal of Forest Science, Bangladesh, 23(1): 41-44.

Lahiry AK (1996), Pole yield of some softwood and hardwood species grown in Bangladesh. J. Timber Development Assoc, India, 42(3): 21-24.

Lahiry AK (1998), Preservative treatment of common timbers and bamboo of Bangladesh for rural electrification infrastructure. International Research Group on Wood Preservation, Document no. IRG/WP 98: 40104.

Lahiry AK (2001), Aplied Wood Preservation. Magnum opus, Dhaka, pp-342-344.

Latif MA, Dasgupta SR and Zaman YU (1987), Preservative treatment of bamboo and low cost housing. Wood preservation series, Bulletin 3, Bangladesh Forest Research Institute, Bangladesh, pp-1-5.

Rana MN, Das AK and Ashaduzzaman M (2015), Physical and mechanical properties of coconut palm (Cocos nucifera) stem. Bangladesh J. Sci. Ind. Res. 50(1): 39-46.

Wangaard FF (1981), Wood: its structure and properties. Forest Products Laboratory, Forest Service, USDA, pp- 1-459.

Winandy JE (1991), Impact of preservative treatment on allowable design stresses. Wood Design Focus, 2(1): 14-16.

Received: 27 July 2015; Revised: 15 October 2015;

Accepted: 19 October 2015. 